\title{
Two words about Cecília Meireles, a name to be remembered
}

\begin{abstract}
This article addresses some relevant facts of the Brazilian writer, educator and poet Cecília Meireles (1901-1964), unfairly forgotten by not a few of her compatriots. Used to deal with odd situations, Cecilia did not care about following trends and fashions; her poetry is usually considered "Modernist", what is not without reason, given her unfailing readiness to make it new, as touchstone of the movement (actually an Ezra Pound's injunction) goes. She did not, however, said a radical no to the culture of the past, as rejecting it as a something merely "obsolete", as many of her contemporaries did (consider Dadaism).
\end{abstract}

Keywords: Cecília Meireles, art, poetry, Brazil, preservation of culture

\author{
Volume 4 Issue 5 - 2019
}

\author{
João Vicente Ganzarolli de Oliveira \\ Senior Professor \& Researcher,Tércio Pacitti Institute, Federal \\ University of Rio de Janeiro, Brazil
}

\author{
Correspondence: João Vicente Ganzarolli de Oliveira, \\ Senior Professor \& Researcher, Tércio Pacitti Institute, Federal \\ University of Rio de Janeiro, Brazil, Av. Pedro Calmon, 550, \\ Cidade Universitária, Rio de Janeiro (RJ, 2194I-90I), Tel +552I- \\ 3938-9600,Email jganzarolli@usa.com
}

I have learned from the springs to let myself cut Sanskrit, what was no mean feat at all! Cecília also translated into and to return always in one piece. Portuguese some of the most relevant names of modern literature, such Cecília Meireles as Maeterlinck, Federico García Lorca, Anouilh, Ibsen, Tagore, Rilke,

\section{Introduction}

Biographers of the Brazilian poet Cecília Meireles (1901-1964) use to highlight the fact that she was "orphaned at age three and raised by her maternal grandmother." Being nothing more than an admirer of her person and her work, I am in no condition to say if orphanhood is directly related to her literary career or not. What is certain is that she did not choose to become a poet because she was an orphan; such causal link does not-and in fact could not-exist. Nobody chooses to write poetry in the same way as nobody chooses to paint canvases or to play the piano, provided that we are talking about art in its genuine aesthetical sense, which is that of producing beauty-complementing, this way, the beauty nature already produces. ${ }^{2}$ In other words, we are not the ones who chose to become artists; it is up to her, the art, to choose us. As for Cecília Meireles, no doubt that being an orphan since the age of three has something to with the subject of much of her poetry; indeed, her verses are permeated by a sense of absence and loss, as Helen Ferreira Nunes points out in her Master's dissertation. ${ }^{3}$ Almost alone in the world (more was to come: she also lost her brothers and her first husband, who committed suicide), Cecília sought refuge in religion-being religiousness not a common feature, at least explicitly, of her work. Indeed, "Meireles was a devout Catholic, but did not emphasize her religious or social stands" (Figure 1).

\section{Who was she?}

Daughter of Azoreans, Cecília inherited the typical Portuguese passion for navigating toward distant lands. She definitely travelled a lot; the sea became for her a recurrent refrain and she fell in love with India. Already a multilingual, she taught herself Hindi and even

\footnotetext{
${ }^{1}$ Stephen Tapscott, et al. Twentieth century Latin American poetry: a bilingual anthology. Austin: University of Texas Press, 1996. p. 160.

${ }^{2}$ See Gianni Carchia, Paolo D'Angelo et al. Dizionario di estetica. Laterza: Roma/Bari; 1999. p. 37-43.

${ }^{3}$ Memória da ausência em Cecília Meireles. Master's dissertation, Ouro Preto, UFOP, 2015. p. 14 et passim.

${ }^{4}$ Raymond Sayers et alii. https://en.wikipedia.org/wiki/Cec\%C3\%ADlia Meireles 2019.
}

Virginia Woolf and Pushkin. In spite of being "widely considered the best female poet from Brazil", ${ }^{5}$ Cecília is not mentioned in books where she should have been, e.g., Edwin Williamson's The Penguin History of Latin America. Many Brazilians do not know either who exactly she was, nor what she meant for Brazilian culture as a whole. For a significant number of citizens of Rio de Janeiro (Cecília's hometown), "Cecília Meireles" is nothing more than "the name of a small concert hall"-which, by its turn, has never been visited by those same citizens (Figure 2).

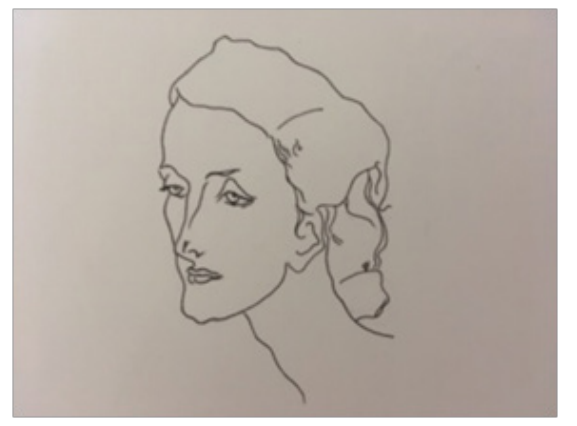

Figure I Cecilia Meireles: Drawing made by the Author, after Arpad Szénes.

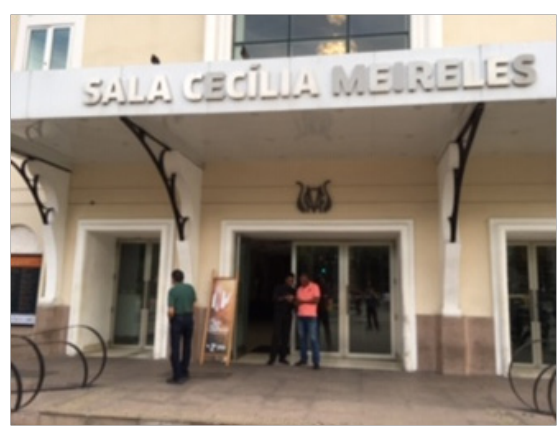

Figure 2 Sala Cecília Meireles (Photo taken by the Author).

\footnotetext{
${ }^{5}$ Raymond Sayers et alii. https://en.wikipedia.org/wiki/Cec\%C3\%ADlia Meireles 2019.
} 


\section{Conclusion}

Used to deal with odd situations, Cecília did not care about following trends and fashions; her poetry is usually considered "Modernist", what is not without reason, given her unfailing readiness to make it new, as the touchstone of the movement (actually an Ezra Pound's injunction) goes. She did not, however, say radical no to the culture of the past, rejecting it as something merely "obsolete", as many of her contemporaries did (consider Dadaism). Never afraid of swimming against the tide, Cecília Meireles- who, besides a poet, was also a writer and an educator-seems to have turned her creative skills mainly to the transitory and hence perishable, aspect of the beauty present in the world. Her aim, as a poet, was to depict this beauty, granting it perpetuity. ${ }^{6}$ Sure about the existence of God, Creator of Nature and the Universe as a whole, Cecília lived up to Dante's motto, according to which the art is like a grandson of Him (arte a Dio quasi è nipote $^{7}$ ) (Figure 3). ${ }^{1-6}$

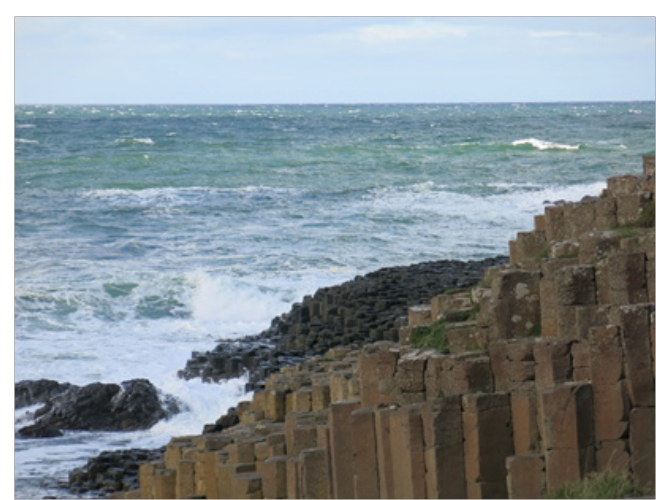

Figure 3 Cecilia was particularly fond of the sea (Giant's Causeway, Ireland [photo taken by the Author]).

\footnotetext{
"See, for instance, Darcy Damasceno. "Poesia do sensível e do imaginário", in Cecília Meireles. Obra poética, Rio de Janeiro: José Aguilar; 1967. p. 21 et passim.

${ }^{7}$ Inferno, XI, 105 .
}

\section{Acknowledgments}

None.

\section{Conflicts of interest}

Author declares that there is no conflict of interest.

\section{References}

1. Carchia Gianni, D'angelo Paolo. Dizionario di estetica. Laterza: Roma/ Bari; 1999.

2. Damasceno Darcy Damasceno. Poesia do sensível e do imaginário in Cecília Meireles. Obra poética. Rio de Janeiro: José Aguilar; 1967.

3. Dante Aliguieri. La Divina Commedia. $16^{\text {a }}$ ed. Milan: Ulrico Hoelpi; 1955.

4. Nunes Helen Ferreira. Memória da ausência em Cecília Meireles. Ouro Preto: UFOP; 2015

5. Sayers Raymond et al. 2019.

6. Tapscott Stephen. Twentieth century Latin American poetry: a bilingual anthology. Austin: University of Texas Press; 1996. 